\title{
主成分による教師なしの学習パターン識別
}

\author{
今 井 敏 雄 - 志 村 正 道 \\ 大阪大学基整工学部 豊中市待兼山町 1-1 \\ (昭和 47 年 6 月 5 日 受付)
}

\section{Nonsupervised Pattern Classification Using the Principal Component}

\author{
Toshio Imai and Masamichi Shimura \\ (Faculty of Engineering Science, Osaka University, Toyonaka) \\ (Received June 5, 1972)
}

Most pattern recognition problems may be categorized as parametric and nonparametric ones on the bases of our knowledge concerning the conditional densities of the input patterns. In addition, the learning machines can further be classified into two types, supervised and nonsupervised ones.

This paper presents a mathematical model of a nonsupervised learning machine using a first principal component. Previous works related to the classifying method using the first principal component, such as those by Cooper and Cooper, and Takanuki and Morishita, have led to a nonsupervised classifiers with parametric learning methods.

In this paper, we discuss a nonparametric case. Under the assumption that the patterns of each category are clustered, the separating hyperplane should contain the mean vector $Z_{s}$ of all patterns used and should be perpendicular to the line governed by the first principal component $W_{s}{ }^{T} X$. Therefore, the decision rule is given by

$$
\text { decide } \begin{aligned}
: X & \in \begin{cases}\mathrm{C}_{1} & \text { if } W_{s} X>\theta_{s} \\
\mathrm{C}_{2} & \text { otherwise }\end{cases} \\
\theta_{s} & =\left(W_{s}, Z_{s}\right) .
\end{aligned}
$$

The learning algorithm employed in the classifier is as follows:

$$
\left\{\begin{array}{l}
W_{k+1}{ }^{\prime}=W_{k}+a_{k}\left\{\left(X_{k}-Z_{k}, W_{k}\right)\left(X_{k}-Z_{k}\right)-\left|X_{k}-Z_{k}\right|^{2} W_{k}\right\} \\
W_{k+1}=W_{k+1}{ }^{\prime} /\left|W_{k+1}{ }^{\prime}\right| \\
Z_{k+1}=Z_{k}+a_{k}\left(X_{k}-Z_{k}\right) \\
\theta_{k+1}=\left(W_{k+1}, Z_{k+1}\right),
\end{array}\right.
$$

where $W_{k}$ is the weight vector, $Z_{k}$ is the mean vector and $a_{k}$ is the correction increment at the $k$-th iteration.

Also we have made a computer simulation to study the learning performance of the classifier for the Gaussian data. The results of the experimental study show that the probability of error of the classifier proposed is slightly larger than the Bayes' minimum error.

1. 序

学習機能をもったパターン認識機械には教師めりの 学習機械と教師なしの学習機械がある.教師ありの学 習機械に招いては，学習パターンの情報と教師が教え
る正解，すなわち学習パターンのカテゴリに関する情 報を用いて，各カテゴリに属するパターンの確率的構 造を推測し，識別機構を逐次学習的に構成する. しか しながら，教師がいない場合には，学習パターンのみ から，その属するカテゴリの推定・決定をしなければ 
ならないすすなわち，パターンの形成する空間の構造 のみがカテゴリの決定の手がかりとなる。したがって, 教師なしの学習機械については, パターンの分布形が わかっている場合の学習方式であるパラメトリックな 学習機械が主汧研究されてきた. 教師なしの学習機械 には, DDM ${ }^{1,2)}$ のように教師のかわりに機械自身の決 定を用いる方法，あるいはパターンの mixture 分布 を学習パターンより推定し，それを各カテゴリの分布 に分解していくことによって識別機構を構成していく 方法などがある．前者の方法は機械自身が正解を与兄 るならば最適な決定（最小誤り）となるといら意味で 準最適な決定方法であるが，SN 比が小さい場合には 学習能率が著しく低下する。また，後者の方法に捻い ては, mixture 分布から各カテゴリの分布に分解する ときの一意性 (identifiability) の仮定が必要とされ る、な技この場合, mixture 分布の推定には, ヒスト グラムあるいは積率を用いる方法 ${ }^{3), 4)}$.などが提案され ている.

教師なしのパラメトリック学習法をもつ識別機械に 物いては，パターンの分布に関する知識が必要とされ るし，また mixture 分布は，一般泣，分布の再生性 をもたないらしとなどから学習過程に掓る学習アル ゴリズムが複雑になる傾向がある。

いっぽう，ノンパラメトリックな学習方法に括いて は，パターンの分布を仮定しないで，あらかじめ定め て和いた識別関数を学習パターンによって逐次修正し ていくが，教師なしのノンパラメトリックな学習機械 としては，Jakowatz がそのモデル6) を提案している。 しかしながら，彼のモデルについて，学習の収束性に 対する証明は特別な場合を除いて困難である.

また，ノンパラメトリックな方法に関する 1 つのア プローチとして，いわゆる教師なしのクラスタ化の方 法7 11) がある。すなおち, 同じカテゴリに属するパタ ーンはクラスタをなすといら仮定のもとに, クラスタ 間導入したある種の距離を用いてクラスタ化の評価 関数を作り，その值を最小にするようにパターン空間 の分割（カテゴリの決定）を行なら方法である。しか しながら，そのアルゴリズムは一般に評価関数の極小 化が保証されているの久であるから，学習過程に括け る初期値の影響が大きく，またすべての学習パターン は繰返し処理されるものであるから，パターンすべて が記憶されていなければならない。

一般に, 教師なしのノンパラメトリックな学習機械 と括いては, パラメトリックな機械のようにパターン の分布関数の形を仮定する必要はないが，乙かしパタ ーンの線形分離可能性, あるいは各カテゴリのパター
ンがクラスタをなすなどといら分布に関する一般的な 仮定がなケれば，その構成は困難となる。

本論交に括いては，多変量解析 ${ }^{12)}$ で用いられる第 1 主成分 (the first principal component) を利用した 教師なしのノンパラメトリック学習法をもつ識別機械 を提案する. 第 1 主成分は $n$ 次元空間のパターンを 1 次元空間，すなわち直線上に射影するときに，その上 でのパターンの分散が最大になるような直線で示され る成分であり，第 1 主成分の荷重ベクトルはパターン の共分散行列の最大固有値に属する基準化された固有 ベクトルとして定められる.

教師なしの場合に括けるパターンの 2 カテゴリ分類 の問題で第 1 主成分を用いる方法として Cooper and Cooper の提案がある14). 彼らは, 各カテゴリの生起 確率が等しく, 各カテゴリのパターンが正規分布で市 る場合に, 学習パターンょり゚゚ターンの平均值拈よび 共分散行列を推定し，反復法によって最大固有值に属 する固有ベクトルを求める方法招よび SN 比が大きい 場合には Decision-Directed 方法を用いる方法を提案 している。また, Ho and Agrawala は全パターンを 繰返して処理することによって上記の固有ベクトルを 求めるアルゴリズムを述べ(0),11), 高貫と森下は制御理 論的なアプローチから微分方程式の安定解として第 1 主成分を求める方法を提案している(15). 本論文では, 確率近似法的なアプローチから，任意の分布形に対し て学習的に第 1 主成分を求める方法を提案する.

な括，計算機シミュレーションを行ない，その実験 結果子示す.

\section{2. 決定理論と学習手順}

パターンに関する情報が事前に与えられていない場 合に和ける教師なしのパターン識別機構について述べ る.いま，パターン $X$ を $n$ 次元ベクトルとし， $k$ 番 目のパターンベクトルを $X_{k}=\left(x_{1}{ }^{k}, x_{2}{ }^{k}, \cdots, x_{n}{ }^{k}\right)^{T}(T$ : 転置) で表わす．これらのパターンを2つのカテゴリ $C_{1}, C_{2}$ に分類する問題を考える.

パターン空間に拈けるパターンの分布は未知である

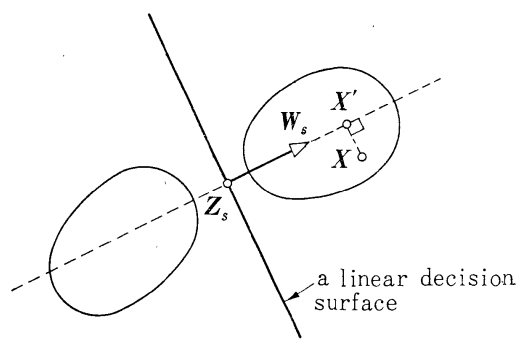

Fig. 1 Geometric interpretation of the decision rule 
が，各カテゴリに属するパターンは Fig. 1 亿示すよ らに，抢の㨟のクラスタをなしているものと仮定しよ う。まず，これらのパターン群に関する第 1 主成分の 荷重ベクトル $W_{s}\left(W_{s}^{T} X:\right.$ 第1主成分）特よび平均 值ベクトル $Z_{s}$ を求める。，一般に，第 1 主成分の荷重 ベクトルは各カテゴリの中心付近をと招り，平均值は

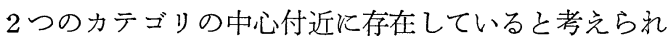
るので, パターンの識別は Fig. 1 に示すように, 平 均值 $Z_{s}$ をと招り，第 1 主成分の荷重ベクトル $W_{s}$ に直交するような分離超平面によって分類される。す なわち, パターン点 $X$ からベクトル $W_{s}$ の方向線上 飞垂直に下ろした点 $X^{\prime}$ が分離超平面のどちら側に属 するかを，いいか觉れば内積 $\left(X-Z_{s}, W_{s}\right)$ の符号に よってパターンの属するカテゴリを決定することがで きる．この場合の決定法則は次のようになる。

$$
\text { decide : } \begin{aligned}
X & \in \begin{cases}C_{1} & \text { if } W_{s}^{T} X>\theta_{s} \\
C_{2} & \text { otherwise }\end{cases} \\
\theta_{s} & =\left(W_{s}, Z_{s}\right)
\end{aligned}
$$

次住, 第 1 主成分の荷重ベクトル $W_{s}$ 特よび平均值 ベクトル $Z_{s}$ を求める学習アルゴリズムについて考察 する. 手順 $k$ 番目に淤将第 1 主成分の推定荷重心 クトル（以後荷重ベクトルと呼ぶ）を $W_{k}=\left(\omega_{1}{ }^{k}, \omega_{2}{ }^{k}\right.$, $\left.\cdots, \omega_{n}^{k}\right)^{T}$, 平均值ベクトルを $Z_{k}=\left(z_{1}^{k}, z_{2}^{k}, \cdots, z_{n}{ }^{k}\right)^{T}$

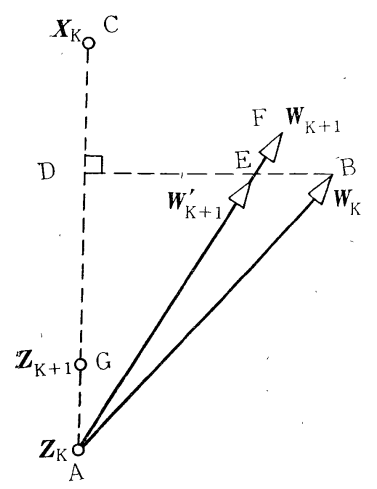
および閾值を $\theta_{k}$ と する、このとき，パ ターン $X_{k}$ が与光ら れると, Fig. 2 亿示 すように, ベクトル $W_{k}$ をパターン $X_{k}$ の方向に $\overrightarrow{\mathrm{BE}}$ だけ傾 计， $W_{k+1}^{\prime}$ をつる。 $W_{k+1}{ }^{\prime}$ はベクトル $\overrightarrow{\mathrm{AE}}$ であり, $W_{k+1}$ はベクトル $\overrightarrow{\mathrm{AE}}$ を 基準化したベクトル $\begin{aligned} & \text { Fig. } 2 \text { Geometric interpretation } \\ & \text { of the learning algorithm } \overrightarrow{A F} \\ & \text { となる. また同 }\end{aligned}$ 時に, $Z_{k+1}$ を $Z_{k}$ より $X_{k}$ の方向に $\overrightarrow{\mathrm{AG}}$ だけずらし た点にとる. 明らかに, パターン $X_{k}$ が荷重ベクトル $W_{k}$ 上にあれば $W_{k}$ は変化させず，また $X_{k}$ が $Z_{k}$ 飞一致していれば $Z_{k}$ を变化させない，

さて, 上で述べた $\overrightarrow{\mathrm{BE}}$ 特よび $\overrightarrow{\mathrm{AG}}$ を

$$
\begin{aligned}
& \overrightarrow{\mathrm{BE}}=a_{k}\left|X_{k}-Z_{k}\right|^{2} \overrightarrow{\mathrm{BD}} \\
& \overrightarrow{\mathrm{AG}}=a_{k}\left(X_{k}-Z_{k}\right)
\end{aligned}
$$

としょう。このとき， $W_{k}, Z_{k}$ 扔よび $\theta_{k}$ に対して， 次のような学習訂正アルゴリズムが得られる.

$$
\left\{\begin{aligned}
W_{k+1}{ }^{\prime} & =W_{k}+a_{k}\left\{\left(X_{k}-Z_{k}, W_{k}\right)\left(X_{k}-Z_{k}\right)\right. \\
& \left.-\left|X_{k}-Z_{k}\right|^{2} W_{k}\right\} \\
W_{k+1} & =\frac{W_{k+1}{ }^{\prime}}{\left|W_{k+1}{ }^{\prime}\right|} \\
Z_{k+1} & =Z_{k}+a_{k}\left(X_{k}-Z_{k}\right) \\
\theta_{k+1} & =\left(W_{k+1}, Z_{k+1}\right)
\end{aligned}\right.
$$

ただし，訂正係数 $a_{k}$ は次の条件を满たすとする.

$$
0<a_{k}<1, \sum_{k=1}^{\infty} a_{k}=\infty \text { かつ } \sum_{k=1}^{\infty} a_{k}^{2}<\infty
$$

したがって，本機械の構造を示すと Fig. 3 のよう になる。

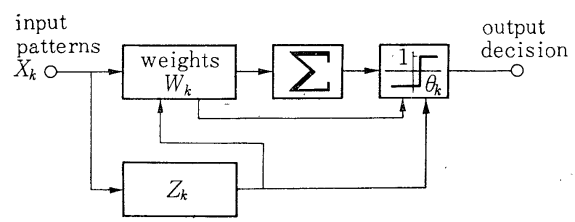

Fig. 3 A block diagram of the nonsupervised machine

\section{3. 学習の収束性}

以下, 前章で求めた学習手順について，先の収束性 を考察しょう。まず，平均值ベクトル $Z_{s}=E\left[X_{k}\right]$ を 求める手順については次の定理 1 を得る。

【定理 1】（4）式で与兄られる手順に招いて, 次の条件

$$
\begin{cases}\text { (a) } & E\left[\left|X_{k}\right|^{2}\right]<\infty \\ \text { (b) } & E\left[\left|Z_{1}\right|^{2}\right]<\infty .\end{cases}
$$

を満足するとき， $Z_{k}$ は確率 1 で $Z_{s}$ に収束する。す なわち、

$$
\text { prob. }\left(\lim _{k \rightarrow \infty} Z_{k}=Z_{s}\right)=1
$$

【証明】（4）式で与兄られる手順が Dvoretzky の定理 (Special Case II) ${ }^{16), 4)}$ の条件を満たしている ことを示せばよい。

まず，（4）式を変形することにより次式を得る.

$$
Z_{k+1}=\left(1-a_{k}\right) Z_{k}+a_{k} Z_{s}+a_{k}\left(X_{k}-Z_{s}\right)
$$

$$
\text { ここで, }\left\{\begin{array}{l}
T_{k}\left(Z_{1}, Z_{2}, \cdots, Z_{k}\right)=\left(1-a_{k}\right) Z_{k}+a_{k} Z_{s} \\
Y_{k}=a_{k}\left(X_{k}-Z_{S}\right) \\
F_{k}=\left(1-a_{k}\right)
\end{array}\right.
$$

と执くと， $\left|T_{k}\left(Z_{1}, Z_{2}, \cdots, Z_{k}\right)-Z_{s}\right|=F_{k}\left|Z_{k}-Z_{s}\right|$

$$
\text { また，（6）式より } F_{k}>0 \text { かつ } \prod_{k=1}^{\infty} F_{k}=0
$$

(7) 式より $\sum_{k=1}^{\infty} E\left[\left|Y_{k}\right|^{2}\right]=E\left[\left|X_{k}-Z_{s}\right|^{2}\right]_{k=1}^{\infty} a_{k}{ }^{2}<\infty$ を得る.そして, 確率 1 で $E\left[Y_{k} \mid Z_{1}, Z_{2}, \cdots, Z_{k}\right]=0$ で あるから,すべての可測関数 $\varphi\left(Z_{1}, Z_{2}, \cdots, Z_{k}\right)$ に対し $\tau$ 
$E\left[\left|\varphi\left(Z_{1}, Z_{2}, \cdots, Z_{k}\right)+Y_{k}\right|^{2}\right] \leqq E\left[\left|\varphi\left(Z_{1}, Z_{2}, \cdots, Z_{k}\right)\right|^{2}\right]$

$+E\left[\left|Y_{k}\right|^{2}\right]$

が成立する。したがって，Dvoretzky の定理の条件 を満足することが知れる。すなおち，（8）式が導か れる。（証明終）

次に, 荷重ベクトル $W_{k}$ の手順についての定理を 示す.

【定理 2】（2）（3）式で与えられる手順に拈い て, 次の条件

$$
\begin{cases}\text { (a) } & E\left[\left|X_{k}\right|^{2}\right]<\infty \\ \text { (b) } & E\left[\left|Z_{1}\right|^{2}\right]<\infty \\ \text { (c }) & \text { パターンの共分散行列 } \\ & \Sigma=E\left[\left(X_{k}-Z_{s}\right)\left(X_{k}-Z_{s}\right)^{T}\right] \\ & \text { の最大固有値は単根である. }\end{cases}
$$

を満足するとき， $W_{k}$ は確率 1 で $W_{s}$ に収束する。す なわら，

$$
\operatorname{prob} .\left(\lim _{k \rightarrow \infty}\left|\left(W_{s}, W_{k}\right)\right|^{2}=1\right)=1
$$

ただし， $W_{s}$ は $\Sigma$ の最大固有值 $\lambda_{\max }$ に属する固 有ベクトルであり，また $\left|W_{s}\right|=1$ である。

【証明】（9）式の（a)（b）扰よび（4）式よ り確率 1 で $\left|X_{k}-Z_{k}\right|^{2}<\infty$ である.ところで，（2）， (3) 式より

$$
\begin{aligned}
& \left(W_{s}, W_{k+1}\right)=\left\{\left(1-a_{k}\left|X_{k}-Z_{k}\right|^{2}\right)\left(W_{s}, W_{k}\right)\right. \\
& \left.\quad+a_{k}\left(X_{k}-Z_{k}, W_{k}\right)\left(W_{s}, X_{k}-Z_{k}\right)\right\} \frac{1}{\left|W_{k+1}{ }^{\prime}\right|}
\end{aligned}
$$

となるから, 次の関係式を得る.

$$
\left|\left(W_{s}, W_{k+1}\right)\right|^{2}=\left|\left(W_{s}, W_{k}\right)\right|^{2}+\frac{1}{\left|W_{k+1}\right|^{2}} A
$$

ただし，

$$
\begin{aligned}
& A=2 a_{k}\left\{\left(X_{k}-Z_{k}, W_{k}\right)\left(W_{s}, X_{k}-Z_{k}\right)\left(W_{s}, W_{k}\right)\right. \\
& \left.-\left(X_{k}-Z_{k}, W_{k}\right)^{2}\left(W_{s}, W_{k}\right)^{2}\right\} \\
& +a_{k}{ }^{2}\left\{\left|X_{k}-Z_{k}\right|^{2}\left(X_{k}-Z_{k}, W_{k}\right)^{2}\left(W_{s}, W_{k}\right)^{2}\right. \\
& -2\left|X_{k}-Z_{k}\right|^{2}\left(X_{k}-Z_{k}, W_{k}\right)\left(W_{s}, X_{k}\right. \\
& \left.-Z_{k}\right)\left(W_{s}, W_{k}\right) \\
& \left.+\left(X_{k}-Z_{k}, W_{k}\right)^{2}\left(W_{s}, X_{k}-Z_{k}\right)^{2}\right\} \\
& \quad\left|W_{k+1}\right|^{2}=1-2 a_{k}\left\{\left|X_{k}-Z_{k}\right|^{2}-\left(X_{k}-Z_{k}, W_{k}\right)^{2}\right\} \\
& \quad+a_{k}{ }^{2}\left|X_{k}-Z_{k}\right|^{2}\left\{\left|X_{k}-Z_{k}\right|^{2}\right. \\
& \left.\quad-\left(X_{k}-Z_{k}, W_{k}\right)^{2}\right\}
\end{aligned}
$$

ここで，(6).式より $\lim _{k \rightarrow \infty} a_{k}=0$ であるから，十分 大きな $k$ に対して $a_{k}{ }^{2} \ll 1$ となり，(12) 式の第 2 項 は無視できる. (13) 式に和いても，第 2 項，第 3 項 は十分小さくなり，| $\left|W_{k+1}\right|^{2}=1$ となる．また，定理 1 より十分大きな $k$ に対しては $Z_{k}=Z_{s}$ となる。 そ れゆ光，(11）式より十分大きな $k$ に対して次式が成 立する。
$\left|\left(W_{s}, W_{k+1}\right)\right|^{2}=\left|\left(W_{s}, W_{k}\right)\right|^{2}+2 a_{k} B_{k}$ ただし，

$$
\begin{aligned}
B_{k} & =\left(X_{k}-Z_{s}, W_{k}\right)\left(W_{s}, X_{k}-Z_{s}\right)\left(W_{s}, W_{k}\right) \\
& -\left(X_{k}-Z_{s}, W_{k}\right)^{2}\left(W_{s}, W_{k}\right)^{2}
\end{aligned}
$$

ここで, (14) 式の $k$ 番目のパターン $X_{k}$ の出現可 能な集合に対する期待値は次のようになる.

$$
\begin{aligned}
E\left[\left|\left(W_{s}, W_{k+1}\right)\right|^{2} \mid W_{k}\right] & =\left|\left(W_{s}, W_{k}\right)\right|^{2} \\
& +2 a_{k} E\left[B_{k} \mid W_{k}\right]
\end{aligned}
$$

(15) 式の第 2 項の条件付期待値は

$$
\begin{aligned}
E\left[B_{k} \mid W_{k}\right] & =\left(W_{s}, W_{k}\right) W_{s}^{T} \Sigma W_{k} \\
& -\left(W_{s}, W_{k}\right)^{2} W_{k}^{T} \sum W_{k}
\end{aligned}
$$

となる.ところで， $W_{s}$ は $\Sigma$ の最大固有值 $\lambda_{\max }$ に 属する固有ベクトルであるから

$$
W_{s}^{T} \Sigma=\lambda_{\max } W_{s}^{T}
$$

でありまた（9）式の条件（c）より，Ws と異な る任意の荷重ベクトル $W_{k}$ に対しては $\left|W_{k}\right|=1$ を考 虑に入れれば

$$
W_{k}{ }^{T} \Sigma W_{k}<\lambda_{\max }
$$

となる、したがって，(16)，(17）㘧よび（18）式よ $\eta$

$$
E\left[B_{k} \mid W_{k}\right]=\left(\lambda_{\max }-W_{k}^{T} \Sigma W_{k}\right)\left(W_{s}, W_{k}\right)^{2} \geqq 0
$$

となり（15）和よび（19）式より十分大きな $k$ に対 しては

$$
E\left[1-\left|\left(W_{s}, W_{k+1}\right)\right|^{2} \mid W_{k}\right] \leqq 1-\left|\left(W_{s}, W_{k}\right)\right|^{2} \quad(20)
$$
なる関係を得る。いっ度う， $1-\left|\left(W_{s}, W_{k}\right)\right|^{2} \geqq 0$ であ るから，1ー|( $\left.W_{s}, W_{k}\right)\left.\right|^{2}$ は Semi-martingale を構成 していることがわかる.したがって, Semi-martingale の収束定理 ${ }^{17)} よ り ~ 1-\left|\left(W_{s}, W_{k}\right)\right|^{2}$ は確率 1 で収束す る.すなわち,

$$
\text { prob. }\left(\lim _{k \rightarrow \infty}\left|\left(W_{s}, W_{k}\right)\right|^{2}=\alpha\right)=1 \quad(\alpha=\text { const. })
$$

(21) 式より $W_{k}$ の極限值 $W_{\infty}$ が存在することが わかるが，ここでもし

$$
\begin{aligned}
\lim _{k \rightarrow \infty} E\left[B_{k} \mid W_{k}\right] & =\left(\lambda_{\max }\right. \\
& \left.-W_{\infty}{ }^{T} \sum W_{\infty}\right)\left(W_{s}, W_{\infty}\right)^{2}>0
\end{aligned}
$$

ならば,（6）式の $\sum_{k=1}^{\infty} a_{k}=\infty$ を考慮すると, (14) 式 より $\left|\left(W_{s}, W_{k}\right)\right|^{2}$ はいくらでも大きくなることにな り，これは $\left|\left(W_{s}, W_{k}\right)\right|^{2} \leqq 1$ に矛盾する。したがって， 極限值 $W_{\infty}$ は

$$
\left(\lambda_{\max }-W_{\infty}{ }^{T} \Sigma W_{\infty}\right)\left(W_{s}, W_{\infty}\right)^{2}=0
$$

を満たさなければならない，ゆえに， $\left|\left(W_{s}, W_{\infty}\right)\right|^{2}=1$ or 0 である. ここで, (20) 式より $\left|\left(W_{s}, W_{k}\right)\right|^{2}$ が 平均的に単調増加することから $\left|\left(W_{s}, W_{\infty}\right)\right|^{2}=1$ であ 
ることぶわかる。すなわち，(21）式で $\alpha=1$ であり， (10) 式を得る.

(証明終)

\section{4. 正規分布パターン}

入力パターンが正規分布をしている場合，すなわち

$$
\left\{\begin{array}{l}
X_{k}=S_{1}+N_{k} \in C_{1} \\
X_{k}=S_{2}+N_{k} \in C_{2}
\end{array}\right.
$$

なる形で与兄られる場合を考觉る。ただし， $N_{k}$ は平 均値 0 , 共分散行列 $\sigma_{N}^{2} I$ の正規分布をするものとす る.このような場合は相加ガウス雑音のある信号検出 の問題となる.

いま，カテゴリ $C_{1}$ 招よび $C_{2}$ のパターンの生ずる 確率が等しく, $P\left(C_{1}\right)=P\left(C_{2}\right)=1 / 2$ と仮定する.この 場合, 明らか飞,

$$
\begin{aligned}
& E\left[X_{k}\right]=\left(S_{1}+S_{2}\right) / 2 \\
& \Sigma=\sigma_{N}^{2} I+\left(S_{1}-S_{2}\right)\left(S_{1}-S_{2}\right)^{T} / 4
\end{aligned}
$$

である.ところで， $\Sigma$ の固有方程式は

$$
\left|\left(\sigma_{N}{ }^{2}-\lambda\right) I+\left(S_{1}-S_{2}\right)\left(S_{1}-S_{2}\right)^{T} / 4\right|=0
$$

となり，上式は次のようにかける (付録参照).

$$
\left(\sigma_{N}^{2}-\lambda\right)^{n-1}\left(\sigma_{N}^{2}-\lambda+\left|S_{1}-S_{2}\right|^{2} / 4\right)=0
$$

それゆ克。

$$
\lambda=\sigma_{N}{ }^{2}(n-1 \text { 重根 }) \text { or } \sigma_{N}^{2}+\left|S_{1}-S_{2}\right|^{2} / 4
$$

となり, 明らか飞 $\Sigma$ の最大固有值

$$
\lambda_{\max }=\sigma_{N}^{2}+\left|S_{1}-S_{2}\right|^{2} / 4
$$

は単根である。したがって，W $\lambda_{\max }$ に属する固有ベクトルとすれば

$$
\begin{aligned}
W_{s}^{T}\left(\sigma_{N}^{2} I+\right. & \left.\left(S_{1}-S_{2}\right)\left(S_{1}-S_{2}\right)^{T} / 4\right)=\lambda_{\max } W_{s}^{T} \\
& =W_{s}^{T}\left(\sigma_{N}{ }^{2}+\left|S_{1}-S_{2}\right|^{2} / 4\right)
\end{aligned}
$$

となる。ここで $\left|W_{s}\right|=1$ を考慮に入れれば

$$
W_{s}=\frac{\left(S_{1}-S_{2}\right)}{\left|S_{1}-S_{2}\right|}
$$

を得る。

ところで一方，ベイズの最小誤り率決定法則は，こ の場同は次のように与光られる。

$$
\text { decide } \begin{aligned}
X & \in \begin{cases}C_{1} & \text { if }\left(S_{1}-S_{2}\right)^{T} X>\Lambda \\
C_{2} & \text { otherwise }\end{cases} \\
\Lambda & =\left(S_{1}-S_{2}\right)^{T}\left(S_{1}+S_{2}\right) / 2
\end{aligned}
$$

（27）式に（23）特よび（26）式を用いれば決定法則 は

decide : $X \in$

$\begin{cases}C_{1} & \text { if } W_{s}^{T} X>\left(W_{s},\left(S_{1}+S_{2}\right) / 2\right)=\left(W_{s}, Z_{s}\right)\end{cases}$

となり，前章で与兄た決定法則（1）と一致するす なわち, 上述の場合，ここで提案する教師なしの機械 はベイズの最小誤り率機械に収束することが知れる.

\section{5. 計 算 機 実 験}

以下に計算機実験の結果を示す。ここで行なった実 験は 20 次元パターン $(n=20)$ を 2 つのカテゴリ $C_{1}$, $C_{2}$ に分類する問題である. ここで, 各カテゴリの生 起確率は等しく, $P\left(C_{1}\right)=P\left(C_{2}\right)=1 / 2$ とする. カテゴ リ $C_{1}$ に属するパターンとしては平均值 0 , 共分散行 列 $\sigma_{S}^{2} I$ の正規分布からのランダムサンプル $S_{1}$ に ンダム雑音 (平均值 0 , 共分散行列 $\sigma_{N}{ }^{2} I$ の正規分布) を加光たもの，カテゴリ $C_{2}$ に属するパターンとして は $S_{2}=0$ にランダム雑音を加光たものとした. Fig. 4

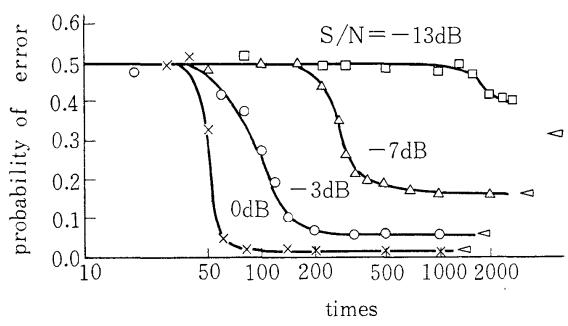

Fig. 4 Learning process of the machine はパターン $S_{1}$ として 3 種類のランダムサンプルを用 いた場合の学習過程に特ける平均誤り率を示したもの であり，学習過程に招いて訂正係数 $a_{k}$ は $a_{k}=1 / k$ と した. 各学習回数に和ける誤り率はパターン200 個に ついて求めた。な特,ベイズの最小誤り率 $P_{B}$ を Fig. 4 に矢印

また，第 1 主成分の寄与率* $\beta_{1}$ は

$$
\beta_{1}=\frac{1+n / 4}{n+\eta / 4}
$$

で表わされ，第 2 以下の主成分の寄与率 $\beta_{i}(i=2,3$, $\cdots, n)$ はすべて等しく

$$
\beta_{i}=\frac{1}{n+\eta / 4} \quad(i=2,3, \cdots, n)
$$

である。ただし， $\eta=\left(S_{1}-S_{2}\right)^{T}\left(S_{1}-S_{2}\right) / \sigma_{N}^{2}$ $n=20$ の場合, $\eta, \mathrm{SN}$ 比, $P_{B}$ 犒よび $\beta_{i}(i=1,2, \cdots$,

n) の関係は Table 1 のようになる.な拉, Fig. 5,

Table 1 The relations of $\eta, \mathrm{SN}$ ratio, $P_{B}$ and $\beta_{i}(i=1, \cdots, 20)$ when $n=20$

\begin{tabular}{r|r|c|c|c}
\hline$\eta$ & $\begin{array}{r}\text { SN } \\
\text { ratio } \\
{[\mathrm{dB}]}\end{array}$ & $P_{B}$ & $\beta_{1}$ & $\begin{array}{c}\beta_{i} \\
(i \neq 1)\end{array}$ \\
\hline 20 & 0 & 0.012 & 0.240 & 0.040 \\
10 & $:-3$ & 0.056 & 0.155 & 0.044 \\
4 & -7 & 0.158 & 0.095 & 0.047 \\
1 & -13 & 0.308 & 0.061 & 0.049 \\
\hline
\end{tabular}

* 主成分 $W_{i}{ }^{T} X$ の寄与率とは $W_{i}{ }^{T} X$ の分散, つ主 成分 $W_{i}{ }^{T} X$ の定める直線上でのパターンの分散 (固有 值 $\lambda_{i}$ に等しい) の総分散 $\left(\sum_{i=1}^{n} \lambda_{i}=\operatorname{trace}(\Sigma)\right.$ に等しい) に対する割合 $\lambda_{i} / \operatorname{trace}(\Sigma)$ である. 


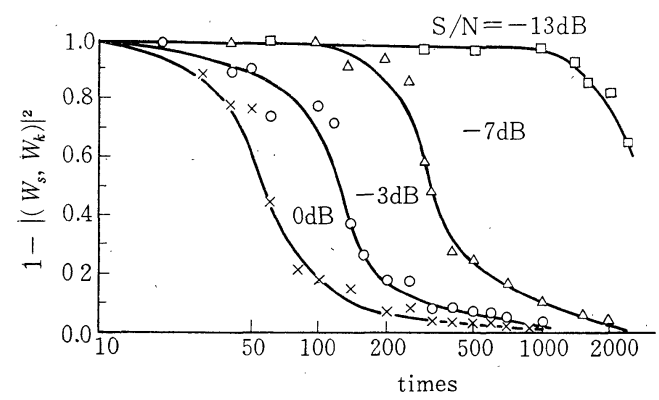

Fig. 5 Convergence process of $1-\left|\left(W_{s}, W_{k}\right)\right|^{2}$

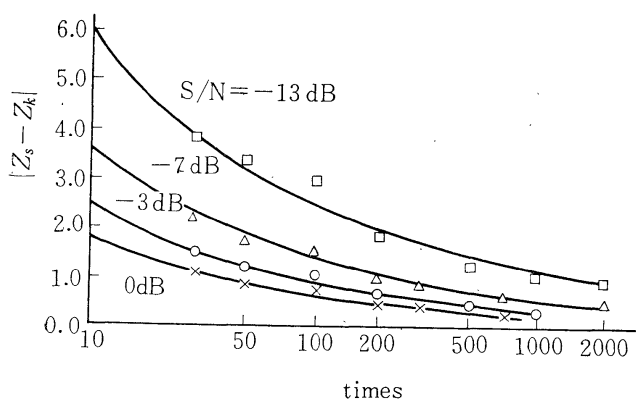

Fig. 6 Convergence process of $\left|Z_{s}-Z_{k}\right|$

Fig. 6 飞 $1-\left|\left(W_{s}, W_{k}\right)\right|^{2}$ と $\left|Z_{s}-Z_{k}\right|$ の収束過程を 示す.

Fig. 4 より $\mathrm{SN}$ 比が $0,-3,-7 \mathrm{~dB}$ の場合それ ぞれ 100,200,500 回程度の学習回数で注とんどべ イズの最小誤り率 $P_{B}$ に収束していることがわかる. な特，SN 比が小さい場合には学習の収束がかなり遅 くなるが，これは第 1 主成分の寄与率 $\beta_{1}$ が，たと兄 ば $\mathrm{SN}$ 比が $-13 \mathrm{~dB}$ の場合には 0.061 であり, 第 2 以下の主成分の寄与率 $\beta_{\imath}(i=2,3, \cdots, 20)$ が 0.049 で あることからもわかるように, パターン空間での第 1 主成分の特徵が明確でなくなり, 探索が困難となるか らである。しかしながら，このような傾向は一般の機 械にも共通した問題である.

\section{6. 結 言}

本論文では主成分を用いた教師なしのノンパラメト リック学習法をるつ識別機械を提案し，その構成扣よ び学習アルゴリズムを示した．また，学習に関しては， その収束性の証明を与兄るとともに，計算機シミュレ ーションを行なって実験的に確かめた．本機械はとく そパターンがクラスタを形成している場合にはきわめ て有用であると考兄られる。

な抒，本機械は，その評価関数として，

$$
\begin{aligned}
J(W, Z) & =E\left[|X-Z|^{2}+|X-Z-(X-Z, W) W|^{2}\right] \\
& =2 E\left[|X-Z|^{2}\right] \\
& -W^{T} E\left[(X-Z)(X-Z)^{T}\right] W
\end{aligned}
$$

を用いたものであるということを付記しておく。すな わち,

$$
\min _{\substack{Z, W \\|W|=1}} J(W, Z)=J\left(W_{s}, Z_{s}\right)
$$

となる。

$$
\text { 参 考 文 献 }
$$

1) H. J. Scudder : Adaptive Communication Receivers, IEEE Trans., IT-11, 2, 167/174 (1965)

2) 田中・田村・樋口：教師なしの学習機能をむつパター ソ識別機械の考察, 信学論 (C), 52-C-2, 112/119 (1969)

3) E. A. Pattric \& J. C. Hancock : Nonsupervised Sequential Classification and Recognition of Patterns, IEEE Trans., IT-12, 3, 362/372 (1966)

4) Y.T.Chin \& K.S.Fu: On Baysian Learning and Stochastic Approximation, IEEE Trans., SSC-3, 1, 28/38 (1967)

5) J.Spragins : A Note on the Iterative Application of Bayes' Rule, IEEE Trans., IT-11, 4, 544/549 (1965)

6) C. V. Jakowatz, et al. : Adaptive Waveform Recognition, Proc. 4 th London Symp. on Information Theory, 317/326 (1961)

7) G. Nagy \& G. L. Shelton : Self-corrective Character Recognition System, IEEE Trans., IT-12, 2, 215/ 222 (1966)

8). K.Fukunaga \& W.L.G. Koontz: A Criterion and an Algorithm for Grouping Data, IEEE Trans., C-19, 10, 917/923 (1970)

9）坂井・金出：繰返しアルゴリズムによる自己適応パタ ーン分類機械について, 信学論 (C), 54-C-11，979/ 986 (1971)

10) Y.H.Ho \& A.K. Agrawala: On the Self-learning Scheme of Nagy and Shelton, Proc. IEEE(Letters), 55-10, 1764/1765 (1967)

11) G. Nagy \& N. Tuong : On a Theoretical Pattern Recognition Model of $\mathrm{Ho}$ and Agrawala, Proc. IEEE (Letters), 56-5, 1108/1109 (1968)

12）奥野-久米- 芳賀 - 吉沢 : 多変量解析法, 日科技連 (1971)

13）磯道: 浮遊円板法, 信学会オートマトン・インホメー ショソ理論研資 (1971)

14) D. B. Cooper \& P.W. Cooper : Adaptive Pattern Recognition and Signal Detection without Supervision, 1964 IEEE Inter'l Conv. Rec., pt. 1, 246/ 256 (1964)

15）高貫・森下：ある自己学習方式を用いるパターン 2 組 分類機械の試作，計測自動制御学会論文集，7-1，17/ 24 (1971)

16) A. Dvoretzky : On Stochastic Approximation, Proc. 3-rd Berkeley Symp. on Math. Stat. and Prob., 1, 39/55 (1956)

17) J.L. Doob : Stochastic Processes, 324, John Wiley (1953) 


\section{$\square$ 付 録 $\square$}

一般に，次の関係式が成立する.

$$
\left|a I+X X^{T}\right|=a^{n-1}\left(a+|X|^{2}\right)
$$

ただし，

\section{【証明】}

$$
X=\left(x_{1}, x_{2}, \cdots, x_{n}\right)^{T}, \quad a: \text { 定数 }
$$

$x_{1} x_{2} \cdots x_{n} \neq 0$ のとき

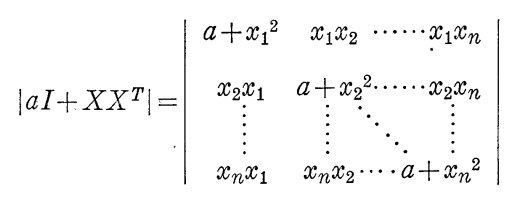

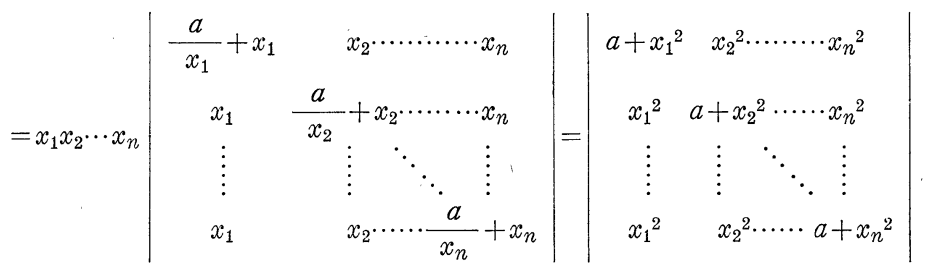

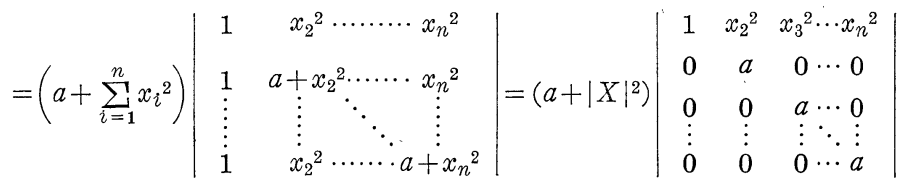

$$
\begin{aligned}
& =\left(a+|X|^{2}\right) a^{n-1}
\end{aligned}
$$

$x_{1} x_{2} \cdots x_{n}=0$ のときも関係式は成立する. 